\title{
A Fall Protection System for High-Rise Construction
}

\author{
Haluk Çeçen ${ }^{1}$ and Begüm Sertyeşilışık ${ }^{2,3}$ \\ ${ }^{1}$ Division of Construction Management, Department of Civil Engineering, Yildiz Technical University, Esenler, 34220 Istanbul, Turkey \\ ${ }^{2}$ Liverpool John Moores University, Liverpool L3 2AJ, UK \\ ${ }^{3}$ Department of Architecture, Istanbul Technical University, Taşkışla Taksim, 34437 Istanbul, Turkey
}

Correspondence should be addressed to Begüm Sertyeşilışık; b.sertyesilisik@ljmu.ac.uk

Received 6 December 2012; Accepted 17 February 2013

Academic Editor: Brian Uy

Copyright (C) 2013 H. Çeçen and B. Sertyeşilıșı. This is an open access article distributed under the Creative Commons Attribution License, which permits unrestricted use, distribution, and reproduction in any medium, provided the original work is properly cited.

\begin{abstract}
In construction industry, the number of fatal and nonfatal occupational injuries is higher than other industries. Among causes of these accidents, "falls" play a key role. This situation reveals the importance for carrying out research in fall protection systems. In this paper, a practical, economical, and functional fall protection system is introduced. Following determination and evaluation of existing solutions, weekly brainstorming meetings were held among the responsible project staff (general coordinator, project coordinator, project manager, site manager, and health and safety manager). As a result of these meetings, design criteria were developed. Based on these criteria, the fall protection system for high-rise construction (FPSFHC) was developed which satisfied all the specified design criteria. Required materials were procured from local dealers. In this paper, criteria used in design and details of the final design are presented. Field performance of the system is evaluated, and recommendations for further development and standardization of the system are added.
\end{abstract}

\section{Introduction}

The fall protection system for high-rise construction (FPSFHC) was developed in June 2006 during the construction of the Federation Tower, Moscow, Russia (a 63 -storey- $243 \mathrm{~m}$ high reinforced concrete skyscraper built by the Turkish contractor ANT YAPI, the tallest building in Russia in 2006). Due to the high-rise nature of the building construction, construction safety was an important concern. Thus, a special safety team was formed, and conventional safety precautions were taken. Nevertheless, a fatal accident which involved the fall of a worker from upper stories could not be prevented. This was due to a sudden gust of unprecedented strength. That accident has triggered an urgent on-site research and development process. The target was to develop a fall protection system for the upper working levels of the high-rise building construction.

\section{A Literature Survey}

In construction industry, rates of fatal and nonfatal occupational accidents are higher compared to other industries. This fact was emphasized in researches of different authors: Rivara and Thompson [1], Saloniemi and Oksanen [2], Abudayyeh et al. [3], Waehrer et al. [4], Sorock et al. [5], Jeong [6], Chi et al. [7], and Mohamed [8]. "The average cost per case of fatal or nonfatal injury is $\$ 27,000$ in construction, almost double the per-case cost of $\$ 15,000$ for all industry in $2002 \ldots$ Injury rates and cost rates are higher for construction than for the average of all industries" (Waehrer et al. [4], 1258-1259).

Various researches pointed out the main cause of accidents as "falls": Hinze and Russell [9], Sorock et al. [5], Jeong [6], Rivara and Thompson [1], Huang and Hinze [10], and Hinze [11]. Among them, Jeong [6] evaluated the percentage distribution of deaths and injuries by accident type. According to Jeong's [6] study slip and falls cause $14.50 \%$ of nonfatal injury resulted accidents and $6.80 \%$ of the fatal accidents. Kines [12] indicated that according to studies from many countries preventing falls from heights in construction is necessary to prevent fatal injuries.

Ale et al. [13], who carried out a research on accidents in the construction industry in the Netherlands, pointed out that the percentage of death drastically increases as the height of fall increases and that roof edge protection failure (48\%) 
and failure of fall arrests (28\%) were two of the major causes of fatal fall accidents. Similarly, based on investigation of 508 fatalities due to falls, Hinze and Russell [9] identified the most common causes of falls as follows: off roof, collapse of scaffolding, off scaffolding, collapse of structure, through floor opening, off ladder, off structure, through roof opening, off edge of open floor, and off beam support.

Johnson et al. [14] presented criteria for a fall protection system to be implemented on a wide scale in roof construction. They suggested that such a fall protection system should be economical, flexible, passive, feasible, simple, and protective (Johnson et al. [14]).

In order to increase the efficiency of fall protection system, it must be supported by management. The effect of management commitment to safety on rates of injury and illnesses was emphasized by Heinrich [15], Komaki [16], and Abudayyeh et al. [3].

\section{Methodology Used in Development of Fall Protection System}

The fall protection system developed and presented in this paper satisfies the requirements underlined in the abovesummarized research.

The research to develop a satisfactory fall protection system was carried out in two avenues.

(1) Determination and evaluation of existing solutions upon a swift search of available sources including internet, and one well-known international company (producing formwork systems for reinforced concrete) was contacted and invited to make a proposal. They proposed a fall protection system which used their standard elements coupled with special elements and mechanisms. However, their proposal was not acceptable due to the following drawbacks:

(a) it would involve a heavy and bulky system of steel framework,

(b) it would be on the way of other construction activities,

(c) it would be hard to move up to the next floor,

(d) it would require crane support,

(e) it would take long time to produce and bring on site,

(f) it would require major modifications to be used in construction of other buildings,

(g) it would cost around US\$150.000-200.000.

Several other solutions used in international construction projects were evaluated too. They were not satisfactory either, due to reasons similar to the ones listed above.

(2) Development of a solution on site: the target was the development of a practical, economical, and functional system. For this purpose, weekly brainstorming meetings were held among the responsible project staff (general coordinator, project coordinator,

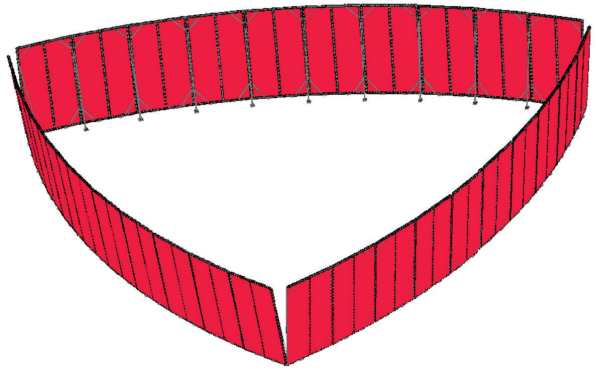

Figure 1: General configuration of FPSFHC.

project manager, site manager, and health and safety manager). To start with, a set of design criteria were developed. Eventually (within a month), the FPSFHC was developed which satisfied all the specified design criteria. Procurement of required materials from local dealers and production of the FPSFHC on site took only two weeks. The production cost of FPSFHC remained within US $\$ 10000$. The proposed system is new due to the fact that it was the first economical, light, and practical modular FPSFHC system with 15degree (with vertical) inclined modules developed in a way to eliminate the above-mentioned drawbacks of the other existing systems.

\section{Design Criteria}

A practical, economical, and functional solution was sought. Reusability was another major criterion. Design criteria used for FPSFHC, presented in Table 1, were determined based on the evaluation of the following:

(i) construction site conditions (availability of materials and site production capabilities),

(ii) the related literature,

(iii) the existing solutions,

(iv) the discussions in the brainstorming meetings among the responsible project staff.

\section{Details of the Design}

FPSFHC is a modular system consisted of a series of panels. Each panel is $3 \times 5 \mathrm{~m}$ in dimension. The enough number of panels is mounted side by side in order to cover the circumference of working floors completely (Figure 1). Details of a panel are shown in Figures 2, 3, and 4. The main frame of a panel is made up of standard pipes $(\varnothing=40 \mathrm{~mm})$. A backbone running along in the middle and four braces $\left(45^{\circ}\right)$ of each corner strengthens the rectangular frame. Two segments (1.5 $\times 5.0 \mathrm{~m}$ ) of steel mesh are spread over each frame and stitched onto the pipes all along the perimeter and the back bone (steel cables $\varnothing=1 \mathrm{~mm}$ were used for stitching). The steel mesh is made up of steel wires $(\varnothing=1.0 \mathrm{~mm}$ ) with openings $15 \mathrm{~mm} \times$ $15 \mathrm{~mm}$ in dimension. 


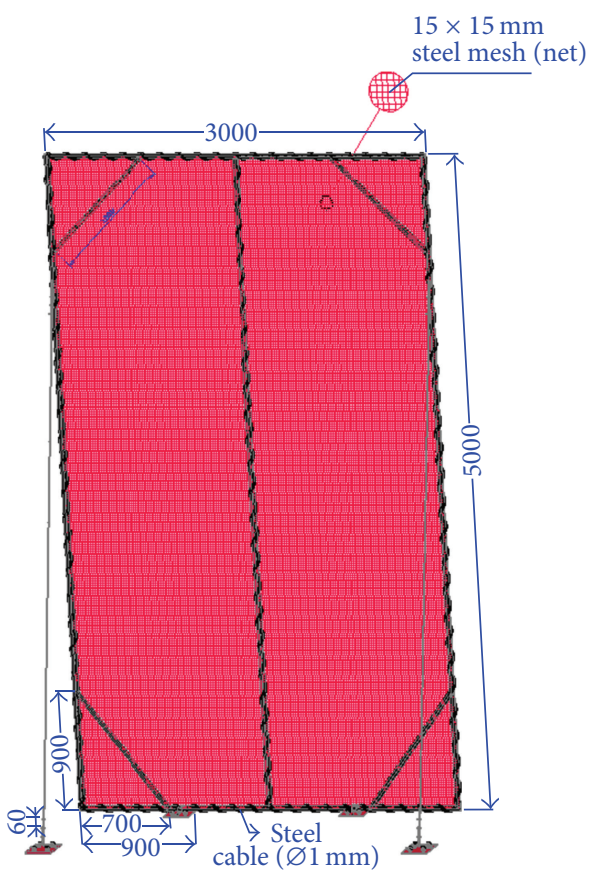

FIgURE 2: Details of panels.

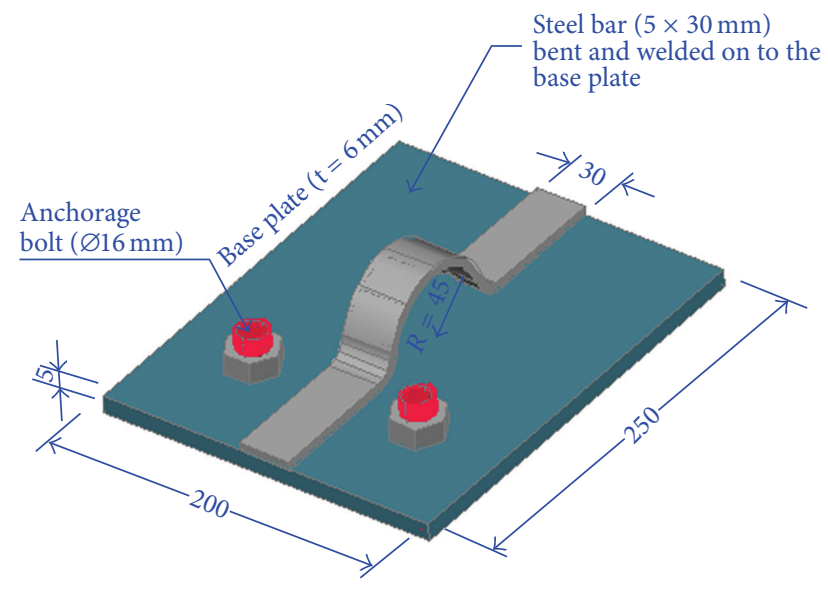

FIgURe 3: Base plate of the panels.

The modular feature of the FPSFHC system provides the following solutions as required due to unusual/irregular plan dimensions of buildings.

(a) The modules may be placed in an overlapping way.

(b) Special modules may easily be produced locally at the construction site.

Base plate details of the panel and that of the connection cables are shown in Figures 3 and 4, respectively.

As seen from Table 1, FPSFHC system was developed based on the following criteria.

Design criterion: strong enough to hold falling man and material.

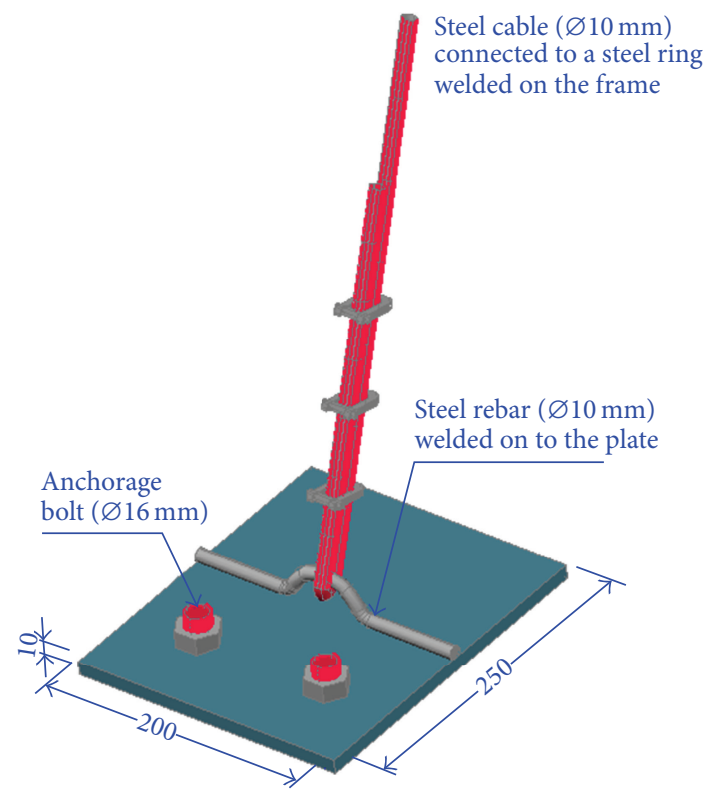

Figure 4: Base plate of the steel cables.

Performance criterion: should hold falling items weighting up to 1 tonne.

Thus, the FPSFHC system was produced to satisfy the above criteria.

Figure 5 shows that panels are mounted in a position that would make an angel about $15^{\circ}$ from the vertical. This way the formwork extensions (approximately $400 \mathrm{~mm}$ ) of the upper floor slab are engulfed in FPSFHC.

Since the falling items would hit the system modules along a 15-degree angle (Figure 5), the angled mounting position of the modules helps to reduce the impact of loads on the modules considerably.

\section{Assembling and Disassembling}

A specially trained team of four workers guided by a health and safety $(\mathrm{H} \& \mathrm{~S})$ foreman handled assembling and disassembling operations. Wearing of proper work outfit, especially the use of safety belts, was strictly enforced.

Each time, two of the upper most working floors of the building construction were enclosed in FPSFHC. Once the first segment of the concrete floor slab of the upcoming floor was casted (which coincided with the striking off the formwork of the lower floor), the panel of the lower floor was started to be disassembled and carried up to the new floor level.

(a) Disassembling steps of the FPSFHC

(1) The anchorage bolts holding a cable are unfastened, and the end of the cable is securely tied onto a column with a rope.

(2) Second cable is secured by the same way.

(3) The anchorage bolts of the anchorage plates at the bottom of the panel are unfastened. 
TABLE 1: Design and performance criteria of FPSFHC.

\begin{tabular}{|c|c|c|c|}
\hline Design criteria & Design & Performance criteria & Performance \\
\hline Economical solution & Inexpensive materials & Production cost $\leq \$ 30000$ & $\begin{array}{c}\text { Satisfied } \\
(\text { cost }=\$ 10000)\end{array}$ \\
\hline Practical solution & $\begin{array}{l}\text { Modular system avoiding bulky } \\
\text { solutions }\end{array}$ & Easy to handle & Satisfied \\
\hline Functional solution & Fall prevention barriers & Protection of working levels & Satisfied \\
\hline No procurement problem & Standard materials & Local availability & Satisfied \\
\hline Easy to produce & Simple rectangular panels & On-site production & Satisfied \\
\hline No need for crane & Light weight panels & Few men to handle & $\begin{array}{c}\text { Satisfied } \\
(4-\text { man team })\end{array}$ \\
\hline $\begin{array}{l}\text { Speedy assembling and } \\
\text { disassembling }\end{array}$ & Light weight modular system & One day per floor & $\begin{array}{c}\text { Satisfied } \\
\text { (8 hours/floor) }\end{array}$ \\
\hline $\begin{array}{l}\text { Not to hinder construction } \\
\text { activities }\end{array}$ & $\begin{array}{l}\text { Mounted in a way that would not } \\
\text { interfere with other construction } \\
\text { activities }\end{array}$ & No obstacle and delay & Satisfied \\
\hline $\begin{array}{l}\text { Fall protection for the two upper } \\
\text { most floors }\end{array}$ & $\begin{array}{l}3 \times 5 \mathrm{~m} \text { panels extending and } \\
\text { protecting the top floor too }\end{array}$ & $\begin{array}{l}\text { Gapless protection all along the } \\
\text { perimeters of the top two floors }\end{array}$ & $\begin{array}{c}\text { Satisfied } \\
\text { (special corner modules) }\end{array}$ \\
\hline $\begin{array}{l}\text { Strong enough to hold falling } \\
\text { man and material }\end{array}$ & $\begin{array}{l}\text { Steel frames }(\text { diameter }=40 \mathrm{~mm} \\
\text { pipes }) \text { covered with steel mesh } \\
(15 \times 15 \mathrm{~mm})\end{array}$ & $\begin{array}{l}\text { Should hold falling items } \\
\text { weighting up to } 1 \text { ton }\end{array}$ & $\begin{array}{c}\text { Satisfied } \\
\text { Held a load }>1 \text { ton } \\
(2-\text { man }+ \text { steel formwork })\end{array}$ \\
\hline No additional wind load & Panels covered with steel mesh & Should stay in place under wind & Satisfied \\
\hline Physiological confidence & $\begin{array}{l}\text { Gapless protection all along the } \\
\text { perimeter of the working floors }\end{array}$ & $\begin{array}{l}\text { Confidence of the construction } \\
\text { workers }\end{array}$ & Satisfied \\
\hline Reusable & Painted steel elements & No damage after repeated usage & Satisfied \\
\hline $\begin{array}{l}\text { Encompass the extensions of } \\
\text { floor formworks }\end{array}$ & Panels placed $15^{\circ}$ from vertical & $\begin{array}{l}\text { Sufficient space for floor } \\
\text { formwork extensions }\end{array}$ & Satisfied \\
\hline
\end{tabular}

(4) The untied panel is pulled inside by three men while the other two helped them by pulling on each cable.

(5) Each recovered panel is carried onto and stored on the material handling platform (a temporary balcony made up of a steel framework) of the same floor.

(b) Assembling steps of FPSFHC

(1) Groups of panel are carried up to the new floor level by crane (the only time crane is used).

(2) Each panel is carried in its place along the rim and is laid on the slab.

(3) Anchorage bolts of the anchorage plates at the bottom of the panel are fastened.

(4) Anchorage bolts of the plates holding the cables are fastened.

(5) The panel is lifted up (by pivoting around the hinges at the bottom of the panel) and is placed in its final position having an angle of $15^{\circ}$ with the vertical.

\section{Performance of the FPSFHC}

FPSFHC had proved its functionality by catching countless falling materials on many occasions. Once it caught a large and heavy piece of steel formwork with two workers on top of it. On-site performance of the system satisfied the design criterion and performance criterion stated in Table 1.

As Moscow has severe weather conditions, the proposed FPSFHC system has been observed to perform well under snowy weather as well. The workers could easily clean off the excessive snow when observed. Besides, additional snow load on the roof at shell-and-core construction stage has not been critical on a high-rise building designed to carry all the dead loads partitions, furniture, and live loads of all floors. It is worth noting that the FPSFHC steel formwork was used for the major columns of the building. The weight of the formwork plus the two workers on top of it was more than 1 ton.

Upon observing this successful site performance, other neighboring constructors started to use similar fall protection systems.

\section{Recommendations for Further Development}

As explained in this paper, the FPSFHC was developed on a construction site within a couple of weeks following a fatal accident. Only locally (Moscow, Russia) available materials were used to manufacture the panel forming the FPSFHC.

Thus, every part of the FPSFHC is open to improvement through research and development. Especially, the connection pieces and details can be improved in order to facilitate quick assembling and disassembling operations. It is believed that well-planned R \& D projects including laboratory tests will produce functional improvements and standardization. 


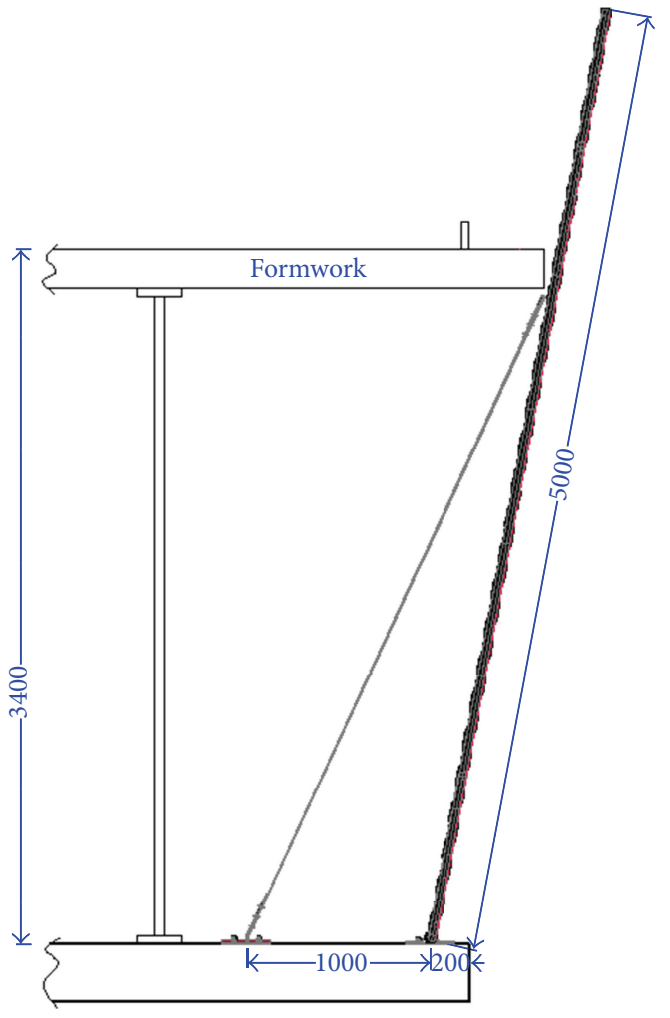

Figure 5: Mounting position of the FPSFHC.

\section{Summary and Conclusion}

FPSFHC was developed to be a practical, functional, and economical fall protection system for upper most working levels of high-rise building constructions. The FPSFHC proved to be as such in the construction of a reinforced concrete skyscraper in Moscow, Russia.

Now that the details of the FPSFHC are shared with the construction industry, the authors sincerely hope that the system will be used throughout the world in order to prevent thousands of fatal and nonfatal accidents that take place each year in constructions of high-rise buildings.

\section{Acknowledgments}

The main idea and basic features of the FPSFHC were developed by Professor Dr. Haluk Cecen then the Project Coordinator of construction of the Federation Tower-B in Moscow, Russia. The authors wish to thank the managers of ANT YAPI for their support for the research and development of FPSFHC. Valuable contributions of the colleagues are greatly appreciated. The following professionals contributed during the final evaluation, approval, production, and execution stages of the FPSFHC: Messers Kadir Tokman, Ertan Yilmaz, Argun Koculu, Ercan Gurbuz, Gurkan Bostanci, Bahtiyar Azeri, Hayati Kalfa, Timur Usta, Nazim Ahiskali (all were Members of ANT YAPI construction company), and Mr. Gleen A. Collins (TURNER Construction Company).

\section{References}

[1] F. P. Rivara and D. C. Thompson, "Prevention of falls in the construction industry: evidence for program effectiveness," American Journal of Preventive Medicine, vol. 18, supplement 4, pp. 23-26, 2000.

[2] A. Saloniemi and H. Oksanen, "Accidents and fatal accidentssome paradoxes," Safety Science, vol. 29, no. 1, pp. 59-66, 1998.

[3] O. Abudayyeh, T. K. Fredericks, S. E. Butt, and A. Shaar, "An investigation of management's commitment to construction safety," International Journal of Project Management, vol. 24, no. 2, pp. 167-174, 2006.

[4] G. M. Waehrer, X. S. Dong, T. Miller, E. Haile, and Y. Men, "Costs of occupational injuries in construction in the United States," Accident Analysis and Prevention, vol. 39, no. 6, pp. 12581266, 2007.

[5] G. S. Sorock, E. O. Smith, and M. Goldoft, "Fatal occupational injuries in the New Jersey construction industry, 1983 to 1989," Journal of Occupational Medicine, vol. 35, no. 9, pp. 916-921, 1993.

[6] B. Y. Jeong, "Occupational deaths and injuries in the construction industry," Applied Ergonomics, vol. 29, no. 5, pp. 355-360, 1998.

[7] C. F. Chi, T. C. Chang, and H. I. Ting, "Accident patterns and prevention measures for fatal occupational falls in the construction industry," Applied Ergonomics, vol. 36, no. 4, pp. 391-400, 2005.

[8] S. Mohamed, "Safety climate in construction site environments," Journal of Construction Engineering and Management, vol. 128, no. 5, pp. 375-384, 2002.

[9] J. Hinze and D. B. Russell, "Analysis of fatalities recorded by OSHA," Journal of Construction Engineering and Management, vol. 121, no. 2, pp. 209-214, 1995.

[10] X. Huang and J. Hinze, "Analysis of construction worker fall accidents," Journal of Construction Engineering and Management, vol. 129, no. 3, pp. 262-271, 2003.

[11] J. Hinze, Construction Safety, Prentice-Hall, Upper Saddle River, NJ, USA, 1997.

[12] P. Kines, "Construction workers' falls through roofs: fatal versus serious injuries," Journal of Safety Research, vol. 33, no. 2, pp. 195-208, 2002.

[13] B. J. M. Ale, L. J. Bellamy, H. Baksteen et al., "Accidents in the construction industry in the Netherlands: an analysis of accident reports using Storybuilder," Reliability Engineering and System Safety, vol. 93, no. 10, pp. 1523-1533, 2008.

[14] H. M. Johnson, A. Singh, and R. H. F. Young, "Fall protection analysis for workers on residential roofs," Journal of Construction Engineering and Management, vol. 124, no. 5, pp. 418-428, 1998.

[15] H. Heinrich, Industrial Accident Prevention, McGraw-Hill, New York, NY, USA, 1931.

[16] J. L. Komaki, "Toward effective supervision: an operant analysis and comparison of managers at work," Journal of Applied Psychology, vol. 71, no. 2, pp. 270-279, 1986. 

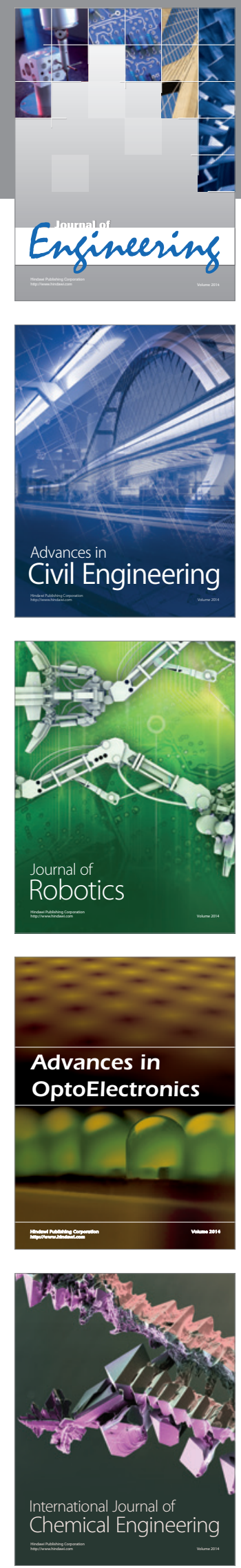

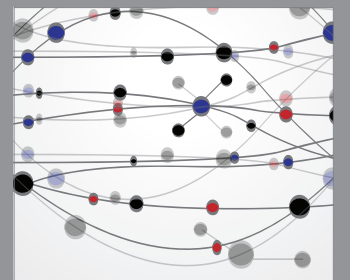

The Scientific World Journal
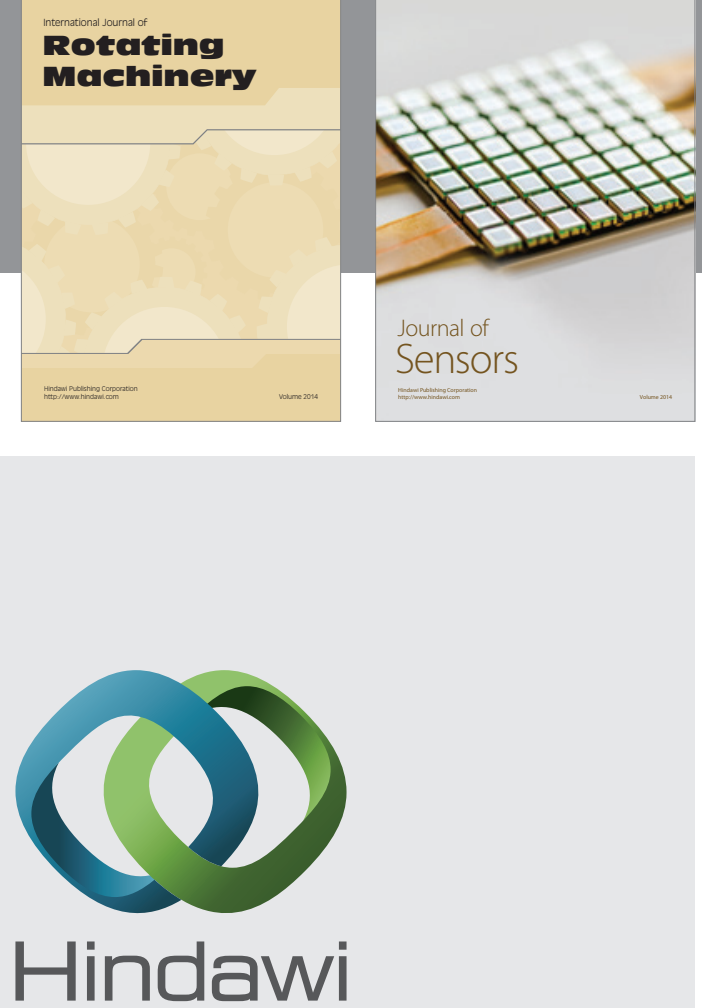

Submit your manuscripts at http://www.hindawi.com
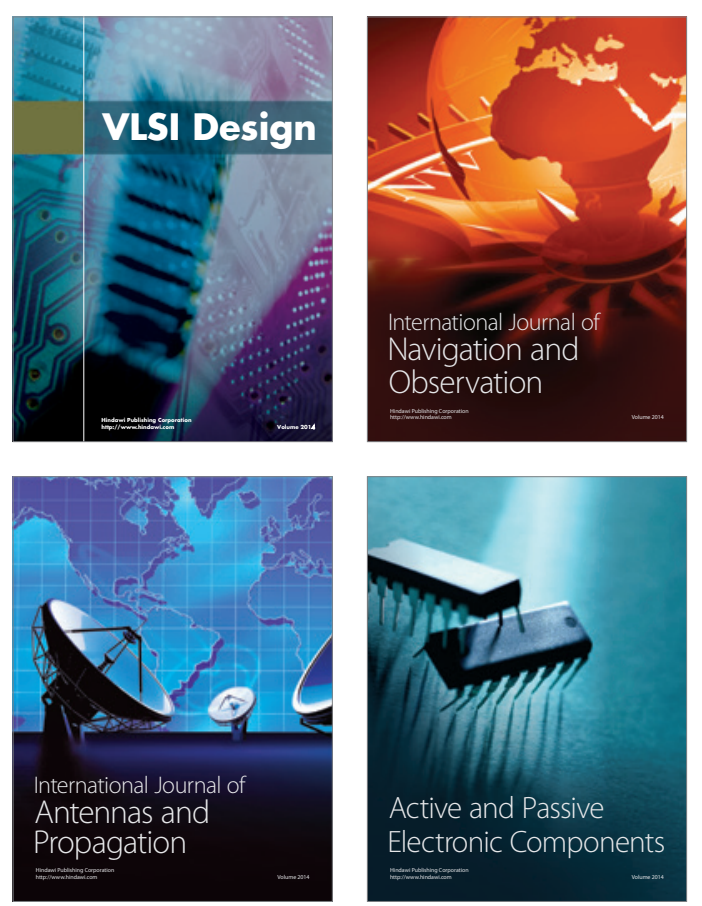
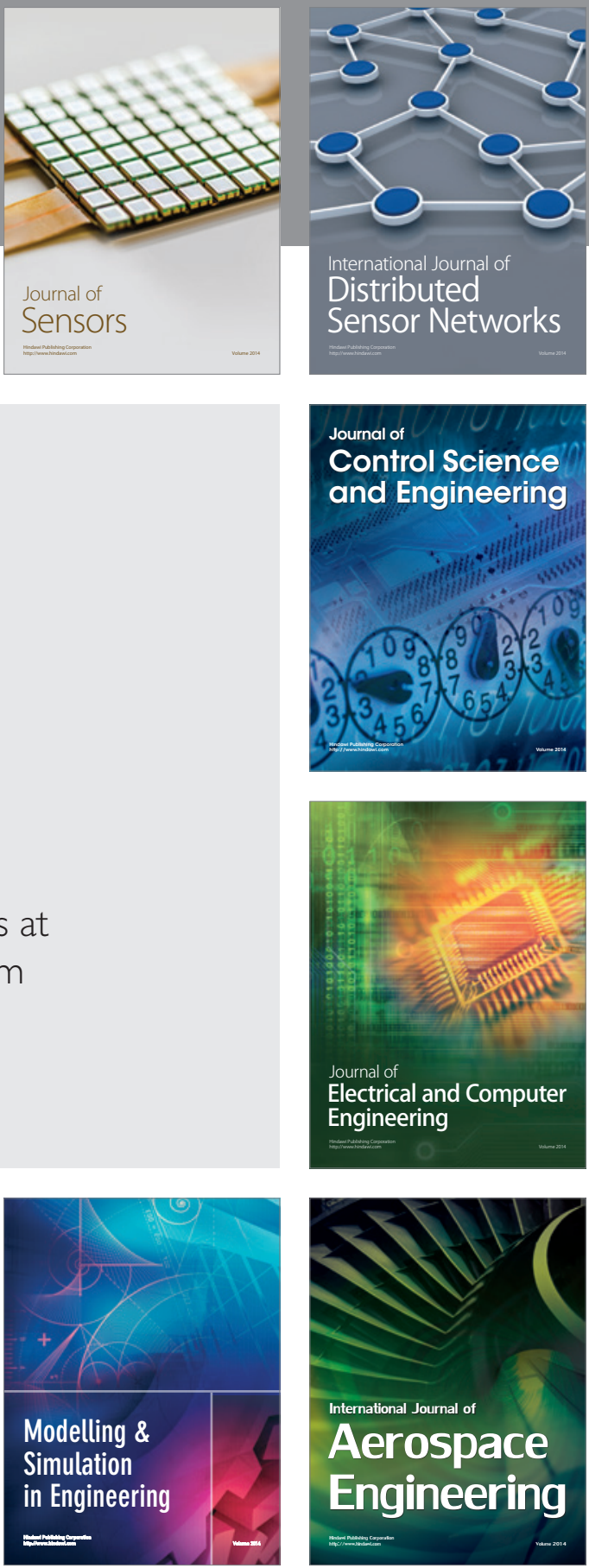

Journal of

Control Science

and Engineering
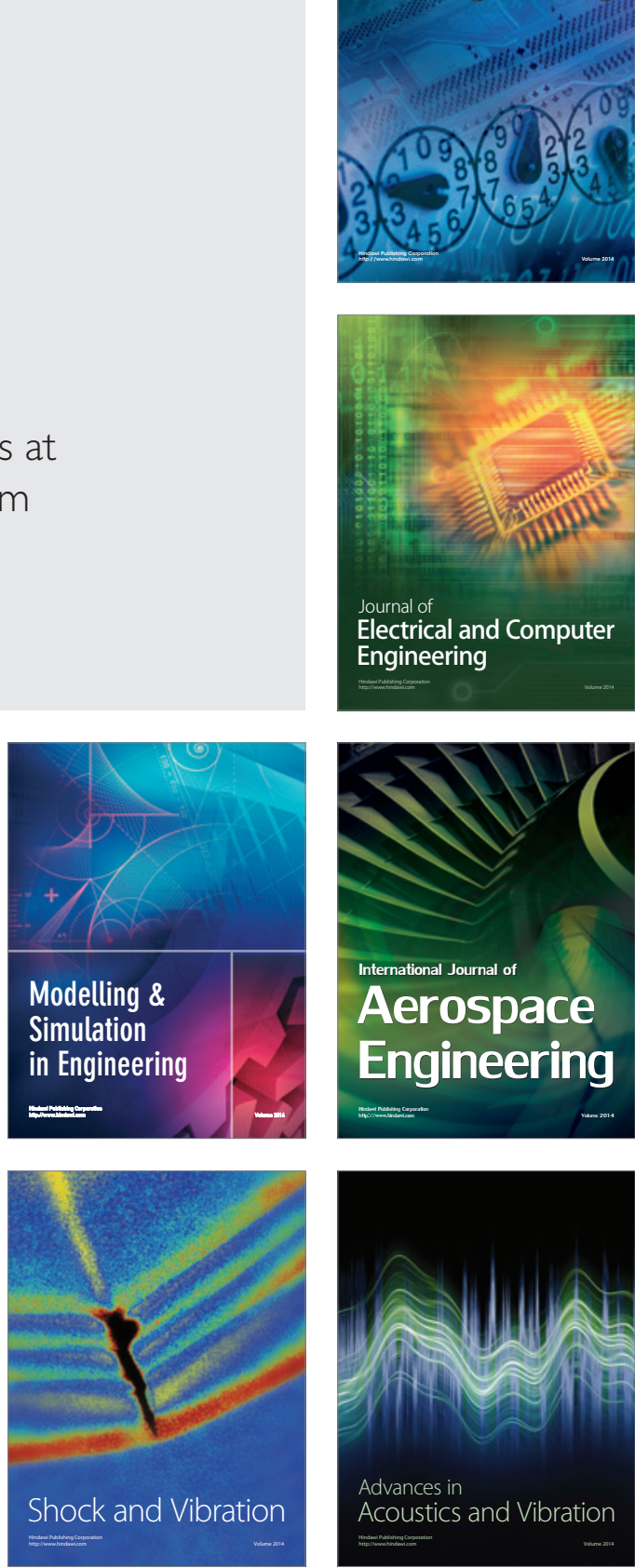